\title{
Leafy branches of Bothrodendron punctatum from the Westphalian D (Asturian) of Nova Scotia, Canada
}

\author{
B.A. Thomas ${ }^{1 *}$, E. Zodrow ${ }^{2}$ And C.J.CleAL ${ }^{3}$ \\ 1. Institute of Biological, Environmental and Rural Sciences, University of Wales Aberystwyth, \\ Llanbadarn Fawr, Aberystwyth, Ceredigion SY23 3AL, UK \\ 2. Cape Breton University, Grand Lake Road, Sydney, Nova Scotia, B1P 6L2, Canada \\ 3. Department of Biodiversity and Systematic Biology, National Museum and Gallery, Cardiff CF10 3NP, UK \\ *Corresponding author:<bat@aber.ac.uk>
}

Date received: 09 September 2009 Date accepted: 16 November 2009

\begin{abstract}
Specimens belonging to the lycopsid genus Bothrodendron are identified by distinctive shoots that have small superficial leaf scars. The species are distinguished on the basis of leaf scar shape and ornamentation on their stem surfaces. Of the two Pennsylvanian (upper Carboniferous) species, Bothrodendron minutifolium has been found several times with leafy shoots attached, but Bothrodendron punctatum has, until now, only been found as large leafless stems. The leafy specimen of Bothrodendron punctatum described here from Cape Breton, Nova Scotia, Canada, is therefore the first of its kind to be found and reveals further evidence of the growth patterns and branch shedding of these relatively rare lycopsids.

\section{RÉSUMÉ}

Les spécimens appartenant au genre lycopside Bothrodendron peuvent être identifiés par leurs pousses distinctives, qui présentent de petites cicatrices foliaires superficielles. Les espèces se différencient par la forme des cicatrices et par l'ornementation de celles-ci sur la surface de la tige. Sur les deux espèces du Pennsylvanien (Carbonifère supérieur), le Bothrodendron minutifolium a été trouvé plusieurs fois avec des pousses feuillues encore attachées, mais le Bothrodendron punctatum trouvé jusqu'à maintenant ne présentait que de larges tiges dépouillées de feuilles. Le spécimen feuillu de Bothrodendron punctatum décrit ici depuis le Cap-Breton, en Nouvelle-Écosse (Canada), est donc le premier en son genre que l'on découvre; il fournit d'autres données de schémas de croissance et de chute de branches de ces lycopsides, qui sont plutôt rares.
\end{abstract}

[Traduit par la redaction]

\section{INTRODUCTION}

Bothrodendron is characterised by having small leaf scars directly on the stem surface, although the narrow, almost terminal shoots of Bothrodendron minutifolium have raised leaf cushions similar to those of Lepidodendron (Thomas 1967b). Ligule pit apertures are clearly visible on Bothrodendron stems, thereby distinguishing them from the superficially similar stems Cyclostigma and Pinakodendron, in which they are never seen. The ligulate genus Lepidobothrodendron Daber 1959 differs from Bothrodendron in having faint cushion outlines enclosing a leaf scar, ligule pit and two external parichnos. (Authorship of and references relating to taxon names are given in Appendix A.).

Some authors, notably Presl (in Sternberg et al. 1838), Lesquereux (1870), Kidston (1885) and Hoffman and Ryba (1899) have confused Bothrodendron with Ulodendron, because the specimen of Bothrodendron punctatum first figured by Lindley and Hutton (1833) has the large oval scars generally known as "ulodendroid" scars. Others took the presence of these large scars to be a criterion of a genus, Ulodendron, and it has even been proposed that differences in the ulodendroid scars could be used for species determination (Walkom 1928). Further work has clearly shown that similar large scars are borne by some typical Lepidodendron stems, e.g. Lepidodendron veltheimii (see Hirmer 1927, fig. 230; Crookall 1964, pl. LXIV, fig. 3; pl. LXXXI, fig. 1; Chaloner 1967, fig. 384) and Lepidodendron nathorstii (see Crookall 1964, pl. LXVI, fig. E; pl. LXVII, fig. 1). Some authors have held that these features represent cone abscission scars, others that they are the result of branch abscission. For further discussion see Kidston (1886), Renier (1908, 1910), Watson (1908, 1914), Seward (1910), Lindsey (1915), Crookall (1964) and Jonker (1976).

Nevertheless the distinction between Bothrodendron and Ulodendron is quite clear, especially since Zeiller (1886a, pl. viii, figs. 1, 1a) figured another specimen of Bothrodendron 
punctatum from Newcastle-upon-Tyne that W. Hutton (coauthor of the species) had given to the Paris Natural History Museum. Ulodendron always has persistent leaves attached to diamond-shaped leaf cushions and never exhibits leaf scars. A ligule pit is present at the base of the adaxial surface of the leaves and can often be seen as a narrow ridge extending downwards from the top corner of the leaf cushions. Cuticle preparations of Ulodendron and other genera have yielded open-ended tubes of cuticle coming from the inner surfaces of the ligule pits (Auerbach and Trautchold 1860; Wilson 1925; Thomas 1967a; 1968a, b). Stomata are also present on both leaves and leaf cushions. Pearson (1986) has shown that the permineralized lycophyte stem Anabathra pulcherrima has coalified leaf laminae and cuticular features closely comparable to those of Ulodendron. For this reason, Pearson included Ulodendron as a synonym of Anabathra. However, the presence of the ulodendroid scars in Bothrodendron is important and relevant to this new specimen, so we will return to this later.

Bothrodendron punctatum and Bothrodendron minutifolium are the only two species known from Pennsylvanian (late Carboniferous) floras. The two species can be easily distinguished from each other on the basis of leaf-scar and stemsurface characters. Bothrodendron punctatum has oval leaf scars up to $2 \mathrm{~mm}$ long with ligule pits contiguous with the top of the leaf scar. The stem surface is covered with fine, sinuous, vertical striations, and the epidermis has uniformly elongated epidermal cells and evenly scattered stomata. In contrast, the oval leaf scars in Bothrodendron minutifolium are laterally elongated and the ligule pit apertures are just separated from the leaf scars. The stem surface is divided into small areas by fine, irregular, undulating horizontal grooves. These areas contain groups of small punctae in horizontal rows that correspond to the stomata seen in cuticle preparations. The epidermal cells form files running obliquely from one stomatal group to another (Thomas 1967b; Jennings 1979). There is thus no basis at all for Renier's (1910) view that Bothrodendron punctatum and Bothrodendron minutifolium are one and the same species.

Bothrodendron minutifolium has small shoots that resemble those of Lepidodendron in possessing small leaf cushions. In the lower parts of these shoots narrow strips of bark separate the cushions, but higher up the cushions are adjacent, whereas at the tips the shoots are leafy and no cushions are visible. The surface markings of grooves and punctae on the leaf cushions are like those on the larger stems. Good illustrations of these smaller stems are given by Zeiller (1886b, pl. 74, figs. 4, 4b), Weiss and Sterzel (1893, pl. 1, fig. 3), Kidston (1902, pl. 54, figs. 1-3), Lindsey (1915, pl. 11, figs. 1-2), Hirmer (1927, figs. 352355), Crookall (1964, pl. 80, figs. 1, 1a), Chaloner (1967, figs. 358-359) and Thomas (1967b, fig. 2). Similar leafy shoots attached to a stem lacking leaf cushions has not been previously recorded for Bothrodendron punctatum and here we document for the first time a specimen showing just such an arrangement. The specimen is from the Sydney Coalfield on Cape Breton Island, Nova Scotia, Canada.

Throughout this paper we have used the Heerlen regional chronostratigraphical scheme that is normally used for Carboniferous sequences in the Canadian Maritimes (see Wagner 1974 for a discussion of the background to this scheme).

\section{DESCRIPTION}

Lindley and Hutton (1833) first described Bothrodendron punctatum from two specimens, one from the roof of the High Main Seam (Duckmantian Substage) of Jarrow Colliery in County Durham and the other from the Percy Main Colliery, Newcastle-upon-Tyne. The former specimen was figured by Lindley and Hutton (1833, pl. LXXX) and Crookall (1964, pl. LXXIII, fig. 5) and is now in the collections of the British Geological Survey (BGS collection no. 5257). The whereabouts of the latter specimen is unknown.

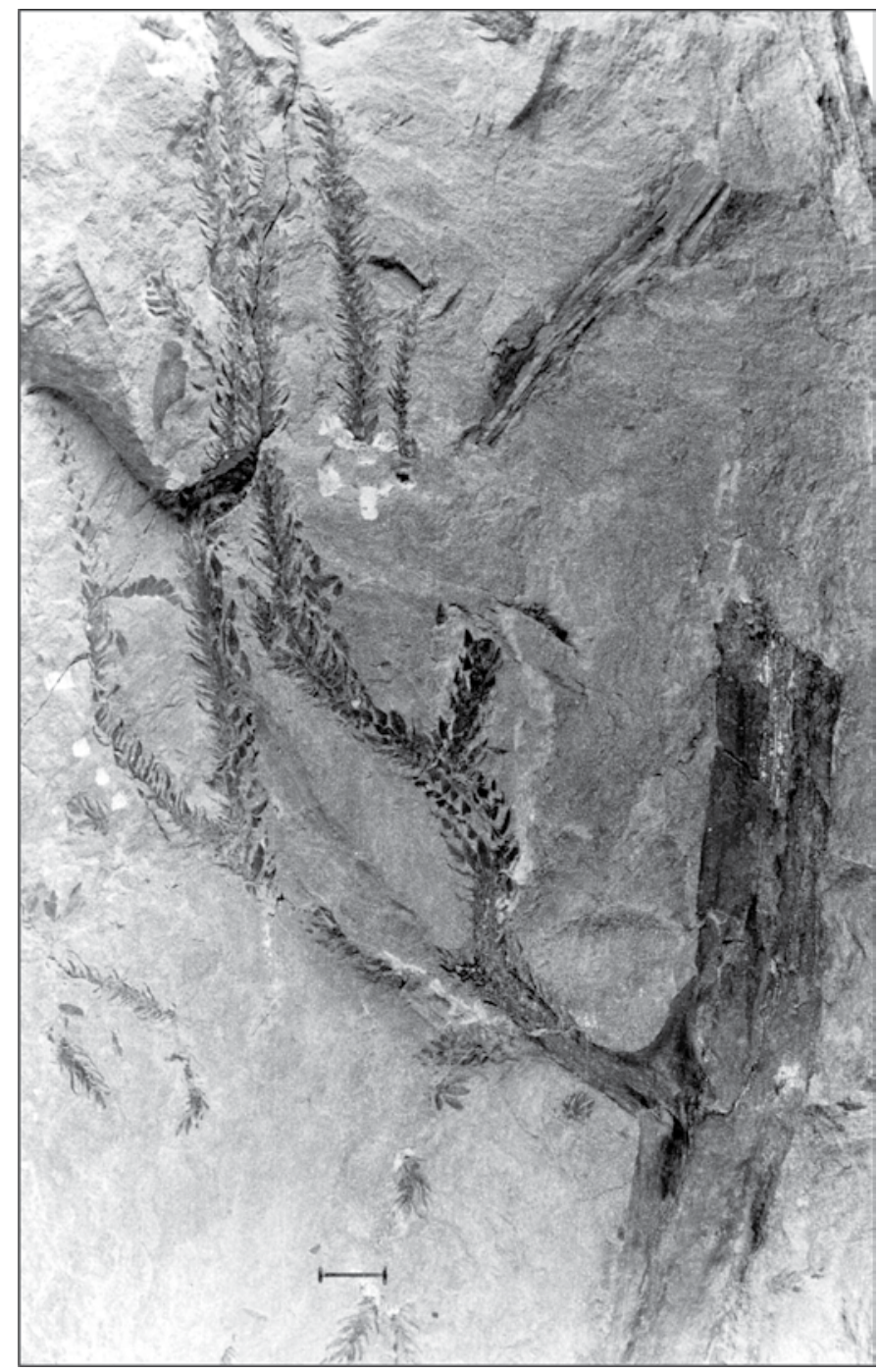

Fig. 1. Bothrodendron punctatum (Nova Scotia Museum, no. 990-281) from the Coal Measures (above the O'Dell/ Gardiner Seam from the Pioneer Coal Mine at Sydney Airport) of Nova Scotia, Canada. Scale bar $10 \mathrm{~mm}$. 
The new specimen (No. 990-281) is from the Morien Group, above the middle/late Asturian O'Dell/Gardiner Seam from the Pioneer Coal Mine at Sydney Airport, Nova Scotia, Canada. It shows the stem ornamentation characteristic of Bothrodendron punctatum. But, unlike any other specimen of this species, it has a main axis with a branching leafy side shoot (Figs. 1-2). The main axis is about $24 \mathrm{~mm}$ across and visible on it are very small leaf scars almost circular in outline and about $0.5 \mathrm{~mm}$ across in low angle spirals of about $10^{\circ}$ and steep spirals of about $60^{\circ}$ (Fig. 3). No foliar prints could be seen in any of the leaf scars. The side shoot departs upwards at an angle of about $20^{\circ}$ with a decurrent upper surface. The side shoot is about 10 $\mathrm{mm}$ across a little way from its broader point of attachment and for the first $20 \mathrm{~mm}$ bears no leaves. The surface of this basal portion of the branch is like that of the main stem and does not have small leaf cushions of the type shown in Bothrodendron minutifolium. The maximum length shown by the side shoot is nearly $20 \mathrm{~cm}$, although it is not complete. The first dichotomy is about. $70^{\circ}$ and the next two are $70^{\circ}$ and $50^{\circ}$ with the axes, by then, having thinned to less than $2 \mathrm{~mm}$ across. The leaves are in tight spirals decurrent and then spreading out at angles of $30-40^{\circ}$ before curving upwards again. Individual leaves are lanceolate, about $0.6 \mathrm{~mm}$ long and about $0.2 \mathrm{~mm}$ across at their broadest point. Their apices are shortly acuminate. These leaves are very similar to those of Bothrodendron minutifolium, but are less densely packed together on the shoots.

\section{DISCUSSION}

As outlined earlier, there has been much debate about the reason for Bothrodendron and some species of Lepidodendron having the large oval/round scars commonly referred to as ulodendroid scars. These have been thought to be abscission scars of flowers (Rhode 1820), roots (Carruthers 1879), bulbils (Stur 1875), cones (Lindley and Hutton 1833; Thomson 1880) and branches (Watson 1908; Renier 1910; Lindsey 1915; Jonker 1976). The evidence now favours them having been formed through branch abscission, especially since Lindsey (1915) described and illustrated two new specimens of Bothrodendron minutifolium, one showing a short stem bearing a mass of dichotomising leafy shoots that has a clean-cut, trumpet shaped base, the other showing a main axis bearing leafy branches that have similar decurrent, trumpet-shaped bases. These specimens suggest that such relatively short branches were lost by shedding along a definite abscission layer. The Nova Scotia specimen of Bothrodendron punctatum is similar to the second specimen of Lindsey's Bothrodendron minutifolium in having a main axis and a leafy side branch that has a trumpet-shaped base. The implication is that this leafy branch might be ultimately shed to produce an ulodendroid scar.

In contrast to Bothrodendron minutifolium, which is relatively widespread in the Pennsylvanian-age macrofloras of Euramerica, Bothrodendron punctatum was much rarer and
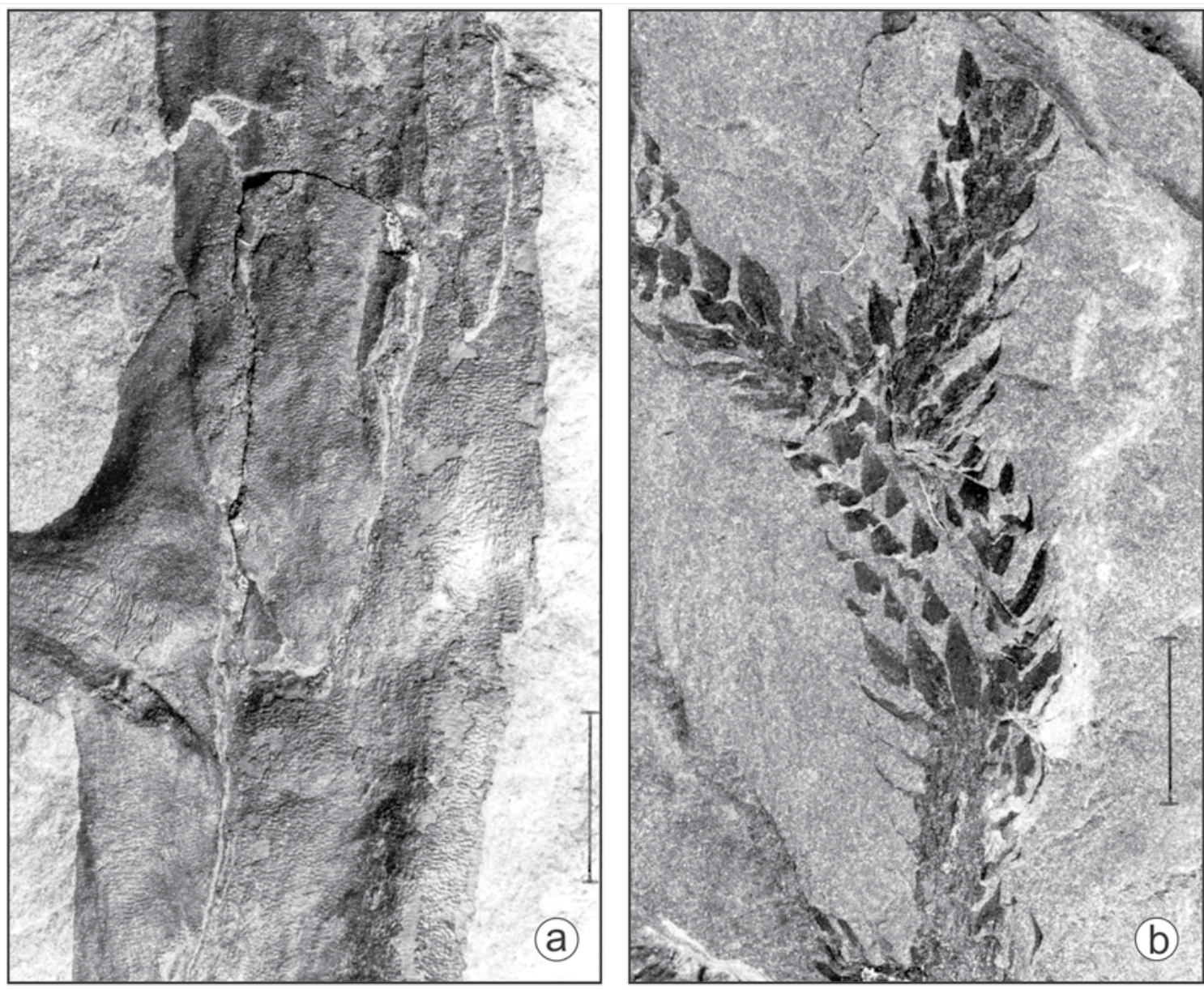

Fig. 2. Bothrodendron punctatum. (a) Area of attachment of the lateral branch and $(b)$ portion of dichotomising leafy shoot. Scale bars 10 $\mathrm{mm}$. 


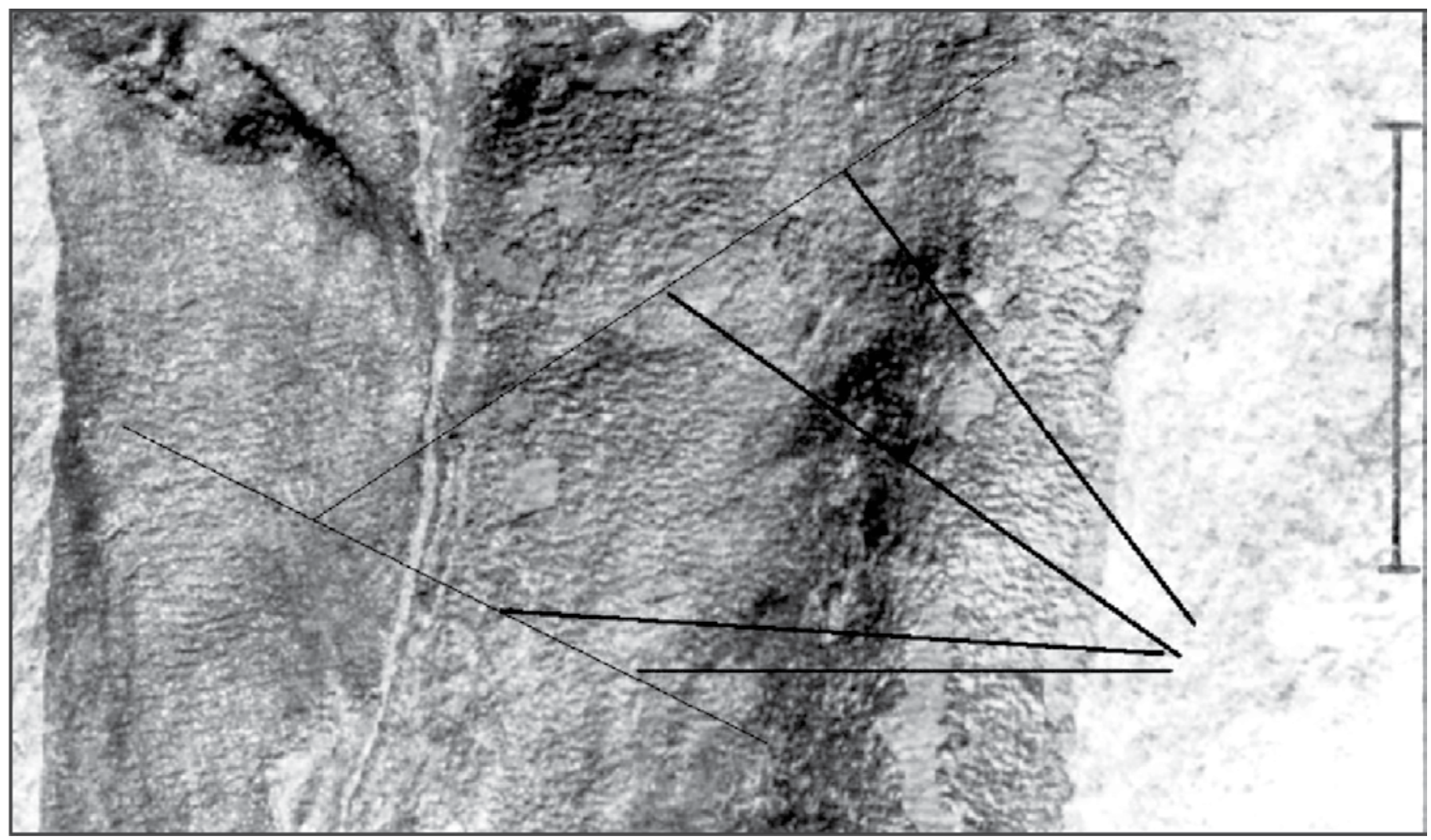

Fig. 3. Bothrodendron punctatum. Angles of whorls shown by the narrow lines. Thicker lines indicate the positions of the leaf scars. Scale bar $10 \mathrm{~mm}$.

had a more restricted geographical distribution. Having checked all of the published records listed in the Fossilium catalogus (Jongmans 1913; Jongmans and Dijkstra 1969), most are either unillustrated and thus unverifiable, indeterminable stems with ulodendroid scars but not showing the bark surface, indeterminable detached leafy shoots, or simple misidentifications usually of Bothrodendron minutifolium. The only verifiable records that we have seen are of Duckmantian age from Britain (Yorkshire, Durham and Ayrshire coalfields; Crookall 1964; Thomas 1967b) and Langsettian age from Nord-Pas-deCalais (Zeiller 1886b; Weiss in Weiss and Sterzel 1893). To this list may now be added the specimen from the Asturian of Cape Breton. There is also a possible record from the Donets Basin in Ukraine - the type of Ulodendron schlegelii. Eichwald (1840) stated that this specimen was very similar to Bothrodendron punctatum, distinguished only by the position of the vascular trace in the ulodendroid scar. Although the illustration of the specimen is too poor to show the details of the stem surface, the description mentions punctae arranged in distinct rows, as is normally seen in Bothrodendron punctatum. It would seem, therefore, that the plant with Bothrodendron punctatum stems was restricted to the very lowland paralic habitats of central and eastern Euramerica, and was absent from the intra-montane basins, or even the slightly more elevated parts of the Variscan Foreland such as Upper Silesia or even the Ruhr.

\section{ACKNOWLEDGEMENTS}

This paper is a contribution to IGCP 469 Late Variscan terrestrial biotas and palaeoenvironments. We thank the Geological Society of London and the University of Cape Breton for financial support and the referees and editor for their constructive comments.

\section{REFERENCES}

Auerbach, J., and Trautchold, H. 1860. Ueber die Kohlen von Central-Russland. Nouvelles Mémoires de la Société Imperial de Nature, 13, pp. 1-58.

Carruthers, W. 1870. On the nature of the stems of Ulodendron, Bothrodendron and Megaphyton. Monthly Microscopical Journal, 2, pp. 144-154.

Chaloner, W.G. 1967. Lycophyta. In Traité de paléobotanique, II. Edited by E. Boureau. Mason \& Cie, Paris, pp. 435-802.

Crookall, R. 1964. Fossil plants of the Carboniferous rocks of Great Britain. (Second section), palaeontology. Memoirs of the Geological Survey of Great Britain (Palaeontology) 4(3), pp. 217-354.

Daber, R. 1959. Die Mittel-Visé-Flore der Tiefbohrungen von Dorberlug-Kirchhain. Geologie Beiheft, 26, pp. 1-83. 
Eichwald, E. 1840. Die Their- und Pflanzenreste des alten rothen Sandsteins und Bergkalks Novogorod'schen Gouvernment. Bulletin Scientifique. Académie Impériale des Sciences de St Petersbourg, 7, pp. 78-91.

Hirmer, M. 1927. Handbuch der Paläobotanik. R. Oldenbourg, Munich and Berlin, $708 \mathrm{p}$.

Hofman, A., and Ryba, A. 1899. Leitpflanzen der palaeozoischen Steinkohlenablangerungen in Mittel-Europa. J. G. Calve \& J. Kochs, Prague. 104 p.

Jennings, J.R. 1979. Lower Pennsylvanian plants of Illinois. III Bothrodendron from the Drury Shales. Journal of Paleontology, 53, pp. 519-523.

Jongmans, W.J. 1913. Fossilium catalogus. II: Plantae. Pars 1: Lycopodiales. W. Junk, Berlin, $52 \mathrm{p}$.

Jongmans, W.J., and Dijkstra, S.J. 1969. Fossilium catalogus. II: Plantae. Pars 72: Lycopodiales VII Supplement. W. Junk, 's-Gravenhage, pp. 1333-1442.

Jonker, F.P. 1976. The Carboniferous "genera" Ulodendron and Halonia an assessment. Palaeontographica, Abteilung B, 157, pp. 97-111.

Kidston, R. 1885. On the relationship of Ulodendron L. \& H. to Lepidodendron Stbg., Bothrodendron L. \& H., Sigillaria Brgt., and Rhytidodendron L. \& H. Annals and Magazine of Natural History, 5, pp. 356-65.

Kidston, R. 1886. Catalogue of Palaeozoic plants in the Department of Geology and Palaeontology, British Museum (Natural History). British Museum (Natural History), London, $288 \mathrm{p}$.

Kidston, R. 1902. Flora of the Carboniferous Period. Proceedings of the Yorkshire Geological and Polytechnical Society, 14, pp. 344-70. doi:10.1144/pygs.14.3.344

Lesquereux, L. 1870. Report on the fossil plants of Illinois. Geological Survey of Illinois, 4(2), pp. 375-508.

Lindley, J., and Hutton, W. 1833. The fossil flora of Great Britain. Volume 2. James Ridgeway, London, xxviii + 208 p.

Lindsey, M. 1915. The branching and branch shedding of Bothrodendron. Annals of Botany, 29, pp. 223-230.

Pearson, H.L. 1986. Structure and taxonomy of the Carboniferous lycopsid Anabathra. Bulletin of the British Museum of Natural History (Geology), 40, pp. 265-292.

Renier, R. 1908. Origine raméole des cicatrices ulodendroïdes du Bothrodendron puntatum L. \& H. Compes Rendu Hebdomadaire des Séances de l'Academie des Sciences, Paris, 146, pp. 1428-1430.

Renier, R. 1910. L'origine raméole des cicatrices ulodendroïdes. Annales de la Société Géologique de Belge, 2, pp. 37-81.

Rhode, J.G. 1820. Beiträge zur Pflanzenkunde der Vorwelt. Grafs, Bartyh \& Cp., Breslau. 40 p.

Seward, A.C. 1910. Fossil plants. A textbook for students of botany and geology. Volume 2. Cambridge University Press, Cambridge. $622 \mathrm{p}$.

Sternberg, K.M. von, Presl, K.B., and Corda, A.C.J. 1838. Versuch einer geognostisch-botanischen Darstellung der Flora der Vorwelt, Volume 2, Parts 7-8. G. Hässe und Söhne, Prague, pp. 81-220.
Stur, D. 1875. Die Culm-Flora des mährisch-schlesischen Dachschiefers. Abhandlungen der Kaiserlich-Königlichen Geologischen Reichsanstalt, 8(1), pp. 1-106.

Thomas, B.A. 1967a. Ulodendron: Lindley and Hutton and its cuticle. Annals of Botany, 31, pp. 775-782.

Thomas, B.A. 1967b. The cuticle of two species of Bothrodendron [Lycopsida: Lepidodendrales]. Journal of Natural History, 1, pp. 53-60. doi:10.1080/00222936700770621

Thomas, B.A. 1968a. The Carboniferous fossil lycopod Ulodendron landsburgii (Kidston) comb. nov. Journal of Natural History, 2, pp. 425-428. doi:10.1080/00222936800770401

Thomas, B.A. 1968b. A revision of the Carboniferous lycopod genus Eskdalia. Palaeontology, 11, pp. 439-444.

Thomson, d'A.W. 1880. Notes on Ulodendron and Halonia. Transactions of the Edinburgh Geological Society, 3, pp. 341-362.

Wagner, R.H. 1974. The chronostratigraphic units of the Upper Carboniferous in Europe. Bulletin de la Société Belge de Géologie, de Paléontologie et d'Hydrologie, 83, 235-253.

Walkom, A.B. 1928. Fossil plants from the Upper Palaeozoic rocks of New South Wales. Proceedings of the Linnean Society of New South Wales, 53, pp. 255-269.

Watson, D.M.S. 1908. On the ulodendroid scar. Memoirs and Proceedings of the Manchester Literary and Philosophical Society, 52, pp. 1-12.

Watson, D.M.S. 1914. On the structure and origin of the ulodendroid scar. Annals of Botany, 28, pp. 481-98.

Weiss, C.E., and Sterzel, J.T. 1893. Die Sigillarien der preussichen Steinkohlen und Rothleigenden Gebeite. Teil 2. Abhandlungen der Königlich Preussischen geologischen Landesanstalt, Neue Folge, 2, 255 p.

Wilson, J. 1925. A note on the structure of the plant cuticles in the Paper-Coal from Toula in central Russia. Manchester Memoirs, 70, pp. 119-123.

Zeiller, R. 1886a. Observations sur les genres, Ulodendron et Bothrodendron. Compte Rendu Sommaire des Séances de la Société Géologique de France, Série 3, 14, pp. 168-182.

Zeiller, R. 1886b. Bassin houiller de Valenciennes, description de la flore fossile (Atlas). Études des Gîtes Mineraux de la France, pls 1-94.

Editorial responsibility: Robert A. Fensome

\section{APPENDIX A: \\ TAXONOMIC NAMES MENTIONED IN TEXT, WITH AUTHORSHIP CITATIONS AND REFERENCES.}

Anabathra Witham 1833 [Internal Struct. Foss. Veg.: 74].

Anabathra pulcherrima Witham 1833 [Intern. Foss. Veg.: 74].

Bothrodendron Lindley and Hutton 1833 [Foss. Fl. Gr. Brit. 2(1): 80].

Bothrodendron minutifolium (Boulay 1876 [Terr. houill. Nord 
Fr.: 39. 1876]) Zeiller 1888 [Compt. Rend. Hebd. Séances Acad. Sci., Ser. 3 14: 180].

Bothrodendron punctatum Lindley and Hutton 1833 [Foss. Fl. Gr. Brit. 2(1): 80].

Cyclostigma Haughton 1860 [J. Roy. Dublin Soc. 2: 12; an illegitimate junior homonym of Cyclostigma Hochstetter ex Endlicher 1844 --- Gen. Suppl. 2: 56].

Lepidobothrodendron Daber 1959 [Geologie Beih. (26) 8: 36]. Lepidodendron Sternberg 1820 [Versuch Fl. Vorwelt 1(1): 19, 23].
Lepidodendron nathorstii Kidston 1885 [Ann. Mag. Nat. Hist. Ser. 5 16: 163].

Lepidodendron veltheimii Sternberg 1825 [Versuch Fl. Vorwelt 1(4): 43, tent. 13].

Pinakodendron Weiss in Weiss and Sterzel 1893 [Abh. Königl. Preuss. Geol. Landesanst. Ser. 2 2: 61].

Ulodendron Lindley and Hutton 1831 [Foss. Fl. Gr. Brit. 1(1): 22].

Ulodendron schlegelii Eichwald 1840 [Bull. Sci. Acad. Imp. Sci. Saint-Pétersbourg 3: pl. 3 fig. 4]. 